\title{
Review Essay: Jacques Derrida: Acts of Religion
}

\author{
Christopher D. Kilgore
}

Jacques Derrida,Acts of Religion, edited by Gil Anidjar (New York: Routledge, 2002).

This collection of Derrida's essays is entitled Acts of Religion, not "thoughts," "essays," or "writings" on religion. It is an appropriate title. These works, selected from Derrida's oeuvre from 1980 to 2001 by Gil Anidjar of Columbia University, constitute an endeavor to clarify and re-think the terms and critical techniques used in philosophical discussions of religion. As Anidjar puts it in his introduction, they "do not merely constitute an exploration of familiar theologemes," but rather consist "of a manifold and powerful effort to situate and raise again questions of tradition, faith, and sacredness and their relation to the premises of philosophy and political culture" (3). This effort is a combination of three separate but interrelated "acts": an act of remembering, an act of looking forward, and an active defense of the ongoing project of linguistic critique itself.

In "Faith and Knowledge," (1996) Derrida examines the philosophical history of the distinction between religion and reason, and formulates a theory of common origin, a 'fiduciary 'link' [that] would precede all determinate community, all positive religion, every onto-anthropo-theological horizon" (55, his italics). This link (the root word, religio) is an act of faith, required to transcend the "one," to reach the absolute other. Understood thus, religion and what he terms "teletechnoscience" stem from the same source; even as they position themselves as opposed, they rely upon one another, and spread together (positioned as opposites), a process that Derrida terms "globalatinization."

This theory of common origin is also a memory of a "sacred language," an 
assessment of notions of originality and translation formulated in "Des Tours de Babel" (1980) and "The Eyes of Language" (late 1980s, published here for the first time). In "Des Tours de Babel," Derrida rereads the story of Babel as an archetypal example of a sacred text, a text that demands translation, but which, once translated, loses its distinctive quality, its status as naming, rather than communication. Stated broadly, "Translation is neither an image nor a copy" (115) of an original text, but rather an outgrowth. In fact, every text implies its own translation-its own translatability.

At the same time, as Derrida highlights in "The Eyes of Language," the act of translation is a "remembering" in its own right, a harkening back to a performative language, the sacred (heilige, unscathed) language of pure naming. In this analysis of Gershom Scholen's 1926 letter to Franz Rozensweig, Derrida explores the concept of the "secularization" - the instrumentalization - of the sacred language (Hebrew). He concludes that, like translation, this secularization is impossible; it is in fact merely a manner of speaking (façon de parler), but that this manner of speaking comprises the very secularization of which it speaks. Both translation and secularization, as acts, point out the impossibility and necessity of a metalanguage, a language for talking about language - a deconstruction.

The violence implicit in the instrumentalization of the sacred language also finds expression, in "Interpretations at War" (1989) and "Force of Law," (1990) as the foundation of the State. These two pivotal essays trace the act of forgetting that erases foundational violence and enables a State to posit itself as just. The founding of law "would consist of a coup de force, of a performative and therefore interpretative violence that in itself is neither just nor unjust" (241). Derrida also undertakes a deconstruction of the opposition between this violence and perpetuating violence (Benjamin's gewalt, legitimized violence), demonstrating that the two cannot be convincingly distinguished. Just as the sacred language returns in explosive outbreaks of unintelligibility (Babel), so does the forgotten violence resurface in new "general strikes" against State authority.

In undertaking these acts of memory, Derrida is also figuring a forward-looking act. As he explains in the two essays on justice and law, each remembered performative event also posits its own "future anterior" (avenir). State violence (the law, gewalt) posits its own existence in a future-perfect tense in order to define (retrospectively) its own foundational, unjustifiable violence as just. It is this game of future presence and absence that forms the basis for his later work in "Hostipitality," a series of lectures from 1997, published here for the first time in Anidjar's translation. Bound up in the "religio," in the link to memory, is a messianic or apocalyptic promise, a redoubled fiduciary link that runs forward as well as backward. These two acts, the (remembered) belief and the messianic avenir constitute for Derrida the foundation of religion, and also of rational linguistic discourse.

By the end of the 1980s Derrida was well aware of the criticisms leveled at his practice of deconstruction, and in particular the objection that it renders justice impossible. His third and final "act" is to refute this claim, in "Interpretations at War" and "Force of Law," the pivotal essays that mark his turn toward religion via an analysis of justice. Through a careful historical treatment of that most unjust, 
unspeakable act, the Nazi "final solution," he proposes that it is precisely the neglect of deconstructive critique, the surrender to gewalt (the law that is violence) that leads to such atrocities. For Derrida, it is vital to see "justice as the possibility of deconstruction, the structure of right or of the law" (243).

Derrida's three "acts of religion" have profound implications for the field of cultural studies. First, he suggests a cautionary reconsideration of the language commonly used to speak about religion in any cultural context. He presents paradoxes that question the separability (let alone opposition) of reason and religion, of religion and tele-technoscience, and of knowledge and belief. His essays are a potent reminder that it is simultaneously impossible and necessary to stand outside of language (or, therefore, culture). Secondly, Derrida also reminds us of the allpervasiveness of religion in human language and experience. Its presence takes the form of the (forgotten, "absent") fiduciary link, the leap of faith from the one to the absolute other (i.e., belief), but also of the avenir, the "future anterior" that posits its own future to establish the present, allowing for the growth of both religion and tele-technoscience. To disregard the role of religion, of the originary moment of faith, of performative (naming) language, of justice, is to disregard the very foundation that makes the metalanguage - the study of anything - both necessary and impossible. 